\title{
Sensory nerve activation in airway microvascular permeability in guinea-pig late allergic response
}

\author{
Y. Mashito, M. Ichinose, H. Sugiura, M. Miura, N. Endoh, K. Shirato
}

\begin{abstract}
Sensory nerve activation in airway microvascular permeability in guinea-pig late allergic response. Y. Mashito, M. Ichinose, H. Sugiura, M. Miura, N. Endoh, K. Shirato. (C)ERS Journals Ltd 1999.

ABSTRACT: Because both bradykinin and tachykinins have a potent inflammatory action, these molecules may be involved in the late allergic response. The role of these molecules in airway microvascular permeability during the late allergic response in sensitized guinea-pigs was investigated.

Three weeks after ovalbumin sensitization, the animals were pretreated with bradykinin $B_{2}$ receptor antagonist $H O E$ 140, neurokinin 1 receptor antagonist $C P$ 96,345 or vehicle, $30 \mathrm{~min}$ before the ovalbumin inhalation challenge. The occurrence of the late allergic response was determined by a two-fold increase in the transpulmonary pressure from the baseline values. The microvascular permeability in the trachea was assessed by an index defined as the ratio of the area of vasculature labelled by Monastral blue dye (area density \%).

Significant microvascular permeability and eosinophil accumulation were observed during the late allergic response. Both the bradykinin and substance $P$ concentrations in the bronchoalveolar lavage fluid were increased during the late allergic response. Pretreatment with HOE 140 suppressed the substance P elevation. Both HOE 140 and CP 96,345 also inhibited the airway microvascular permeability during the late allergic response without affecting the eosinophil accumulation in the airways.

These findings suggest that bradykinin-mediated sensory nerve activation may play a role in microvascular permeability during the late allergic response in guinea-pigs. Eur Respir J 1999; 14: 320-327.
\end{abstract}

First Dept of Internal Medicine, Tohoku University School of Medicine, Sendai, Japan.

Correspondence: K. Shirato

First Dept of Internal Medicine

Tohoku University School of Medicine

1-1 Seiryo-machi

Aoba-ku

Sendai 980-8574

Japan

Fax: 81227177156

Keywords: Airway inflammation

asthma

bradykinin

substance P

Received: September 151998

Accepted after revision March 81999
Bradykinin, a 9-amino acid peptide, is formed from plasma precursors as part of the inflammatory response [1, 2]. Because bradykinin causes vasodilation, airway microvascular leakage [3], mucus secretion, smooth muscle contraction [4] and dyspnoea [5], all of which are the cardinal features of asthma, this molecule may have an important role in the pathogenesis of asthma. There is evidence that the concentration of bradykinin is elevated in the bronchoalveolar lavage fluid (BALF) of asthmatic subjects [6] and increase after allergen challenge [7].

Among the endogenous molecules, bradykinin is the most potent stimulant for sensory C-fibres. Airway C-fibre stimulation may cause the release of tachykinins, such as substance P (SP), into the airways, resulting in neurogenic inflammation $[8,9]$. In fact, in asthmatic airways, bradykinin inhalation induced bronchoconstriction and cough are largely inhibited by a tachykinin receptor antagonist [10], suggesting that the bradykinin-tachykinins pathway may play a key role in the asthmatic airways.

In allergic animal models, the role of the bradykinintachykinins pathway has been examined. BERTRAND et al. [11] have reported that airway microvascular permeability immediately after allergen challenge is significantly inhibited by both bradykinin $\mathrm{B}_{2}$ and neurokinin $1\left(\mathrm{NK}_{1}\right)$ receptor antagonists, indicating the contribution of the bradykinin-tachykinins pathway during that period. In animal models, the late allergic response (LAR) is an important phenomenon because, during this period, the airways show inflammatory features that are very similar to those of asthmatic airway inflammation $[12,13]$. It has been reported that bradykinin in lavage fluid increases during the LAR [14], and that a bradykinin $\mathrm{B}_{2}$-receptor antagonist inhibits the bronchoconstriction during that period [15], suggesting the involvement of bradykinin in airway inflammation during the LAR. However, the role of the bradykinin-tachykinins pathways in the LAR has not yet been fully examined.

The aim of this study was to elucidate the role of the bradykinin-tachykinins pathway in the airway inflammatory responses during the LAR. Using sensitized guinea-pigs, the concentrations of bradykinin and SP in the BALF during the LAR were measured. The occurrence of LAR was assessed while monitoring the transpulmonary pressure $(P \mathrm{tp})$ changes. The functional role of bradykinin and tachykinins in the LAR were measured using selective bradykinin $\mathrm{B}_{2}$ - and $\mathrm{NK}_{1}$-receptor antagonists, respectively. As an inflammatory index, the microvascular permeability was measured by means of Monastral blue dye trapping between the postcapillary venule endothelia, as this site is important for macromolecular leakage. The accumulation of eosinophils into the airways was examined, as this also plays an important role in the inflammation during the LAR. 
Table 1. - Administration of bradykinin $B_{2}$ (HOE 140) and neurokinin $1(\mathrm{CP} 96,345)$ receptor antagonists to guinea-pigs to test inhibition of bradykinin- and substance P-induced airway microvascular permeability

\begin{tabular}{lcccccc}
\hline $\mathrm{n}$ & 5 & 5 & 5 & 5 & 5 & 5 \\
$\begin{array}{l}\text { Pretreatment } \\
\begin{array}{l}\text { Substance } \\
\text { Amount }\end{array}\end{array}$ & $\begin{array}{c}\text { Saline } \\
\mathrm{mL} \cdot \mathrm{kg}^{-1}\end{array}$ & $\begin{array}{c}\text { Saline } \\
1 \mathrm{~mL} \cdot \mathrm{kg}^{-1}\end{array}$ & $\begin{array}{c}\mathrm{HOE} 140 \\
10 \mathrm{mg} \cdot \mathrm{kg}^{-1}\end{array}$ & $\begin{array}{c}\text { DMSO } \\
1 \mathrm{~mL} \cdot \mathrm{kg}^{-1}\end{array}$ & $\begin{array}{c}\text { DMSO } \\
1 \mathrm{~mL} \cdot \mathrm{kg}^{-1}\end{array}$ & $\begin{array}{c}\mathrm{CP} 96,345 \\
50 \mathrm{mg} \cdot \mathrm{kg}^{-1}\end{array}$ \\
$\begin{array}{l}\text { I.v. injection } \\
\text { Substance }\end{array}$ & $\begin{array}{l}\text { Saline } \\
\text { Amount }\end{array}$ & $\begin{array}{c}\text { Bradykinin } \\
1 \mathrm{~mL} \cdot \mathrm{kg}^{-1}\end{array}$ & $\begin{array}{c}\text { Bradykinin } \\
100 \mu \mathrm{g} \cdot \mathrm{kg}^{-1}\end{array}$ & $\begin{array}{c}\text { Saline } \\
1 \mathrm{~mL} \cdot \mathrm{kg}^{-1}\end{array}$ & $\begin{array}{c}\text { Substance P } \\
1 \mu \mathrm{g} \cdot \mathrm{kg}^{-1}\end{array}$ & $\begin{array}{c}\text { Substance P } \\
1 \mu \mathrm{g} \cdot \mathrm{kg}^{-1}\end{array}$ \\
\hline
\end{tabular}

DMSO: dimethy sulphoxide.

\section{Methods}

\section{Animal sensitization}

Male Dunkin-Hartley guinea-pigs (Funabashi Farm, Sendai, Japan) weighing 350-500 g were used. On day 0 and 1, all animals were sensitized with a subcutaneous injection of $10 \mathrm{mg}$ ovalbumin (OVA) and $100 \mathrm{mg}$ aluminum hydroxide [16]. On day 6, all animals were exposed to $2 \%$ OVA in saline using an ultrasonic nebulizer (NE-U12; Omron, Tokyo, Japan; output $0.8 \mathrm{~mL} \cdot \mathrm{min}^{-1}$ ) for $3 \mathrm{~min}$ in a plexiglas exposure chamber $(24.5 \times 40.5$ $\times 15.0 \mathrm{~cm}$ ) under spontaneous breathing. All the experiments performed in this study were conducted with the consent of the Ethics Committee for Use of Experimental Animals of the Tohoku, University school of medicine.

\section{Effectiveness of bradykinin $B_{2}$ and neurokinin 1 antag- onists}

The effectiveness of the bradykinin $\mathrm{B}_{2}$-receptor antagonist $\mathrm{HOE} 140$ and $\mathrm{NK}_{1}$-receptor antagonist CP 96,345 in inhibiting the bradykinin- and SP-induced airway microvascular permeability, respectively, was tested in six groups (table 1). The antagonists or vehicle were administered $6 \mathrm{~h}$ before bradykinin or SP injection, and $1 \mathrm{~min}$ following the injection the vascular permeability was assessed, as described below.

Effect of bradykinin $B_{2}$ and neurokinin 1 antagonists on the late allergic response

On day 21 , the animals were pretreated with pyrilamine $\left(10 \mathrm{mg} \cdot \mathrm{kg}^{-1}\right.$, i.p. $)$ to prevent the animals from dying during the early phase airway response [17]. HOE 140 (s.c.), CP 96,345 (i.p.) or the vehicle thereof were also injected (table 2). Thirty minutes after the pretreatment, the animals were exposed to saline aerosol (control group) or $1 \%$ OVA aerosol (challenged group) for 1 min using the nebulizer system described above. Two hours after the inhalation, all animals were anaesthetized with urethane $\left(2 \mathrm{~g} \cdot \mathrm{kg}^{-1}\right.$, i.p. $)$. A water filled oesophageal catheter (OD $1.52 \mathrm{~mm}$; Natsume Seisahusho, Tokyo, Japan) was inserted to monitor the Ptp. When the Ptp reached twice that of the baseline value in the challenged group (i.e. when the LAR occurred), at $4.5-6 \mathrm{~h}$ after the inhalation, the animals were examined as described below. In the control group; each experiment was performed at almost the same time point during the late phase as in the challenged animals. The dose of pyrilamine was chosen according to a previous study [17].

\section{Quantification of airway microvascular permeability}

Monastral blue dye (particle size 20-300 nm) was sonicated for $5 \mathrm{~min}$ and filtrated using a $5 \mu \mathrm{m}$ Millipore filter (Millipore, Bedford, MA, USA) just before use. One minute after the administration of Monastral blue dye (30 $\mathrm{mg} \cdot \mathrm{kg}^{-1}, i . v$.), the thorax was opened and the systemic and pulmonary circulation perfused with $1 \%$ paraformaldehyde (PFA) in $50 \mathrm{mM}$ phosphate buffered saline (PBS), as previously reported [18]. The lungs were then lavaged twice from the cannulated trachea with $5 \mathrm{~mL}$ saline to measure the bradykinin and SP concentrations as described below. The trachea was removed. The upper part of the trachea was used for eosinophil cell counts and the lower part was immersed in 1\% PFA for $2 \mathrm{~h}$, washed in distilled water for $2 \mathrm{~h}$ and soaked in glycerol for $20 \mathrm{~h}$ at room temperature, followed by dehydration in $100 \%$ ethanol for $1 \mathrm{~h}$ at room temperature. The tissue was immersed in toluene for $1.5 \mathrm{~h}$, then in $100 \%$ ethanol for $1 \mathrm{~h}$, and hydrated in distilled water for $2 \mathrm{~h}$ at room temperature. The hydrated trachea was opened longitudinally

Table 2. - Administration of bradykin $B_{2}$ (HOE 140) and neurokinin 1 (CP 96,345) receptor antagonists to sensitized guinea-pigs to test effect on the late allergic response

\begin{tabular}{|c|c|c|c|c|c|}
\hline \multicolumn{6}{|l|}{ HOE 140} \\
\hline $\mathrm{n}$ & 5 & 5 & 5 & 5 & 5 \\
\hline Pretreatment s.c. & $\begin{array}{l}\text { Saline } \\
\left(1 \mathrm{~mL} \cdot \mathrm{kg}^{-1}\right)\end{array}$ & $\begin{array}{l}\text { Saline } \\
\left(1 \mathrm{~mL} \cdot \mathrm{kg}^{-1}\right)\end{array}$ & $\begin{array}{l}\text { HOE } 140 \\
\left(0.1 \mathrm{mg} \cdot \mathrm{kg}^{-1}\right)\end{array}$ & $\begin{array}{l}\mathrm{HOE} 140 \\
\left(1 \mathrm{mg} \cdot \mathrm{kg}^{-1}\right)\end{array}$ & $\begin{array}{l}\text { HOE } 140 \\
\left(10 \mathrm{mg} \cdot \mathrm{kg}^{-1}\right)\end{array}$ \\
\hline Challenge & Saline & OVA & OVA & OVA & OVA \\
\hline \multicolumn{6}{|l|}{ CP 96,345} \\
\hline $\mathrm{n}$ & 5 & 5 & 5 & & \\
\hline Pretreatment s.c. & $\begin{array}{c}\text { DMSO } \\
\left(1 \mathrm{~mL}^{\left.-\mathrm{kg}^{-1}\right)}\right.\end{array}$ & $\begin{array}{c}\text { DMSO } \\
\left(1 \mathrm{~mL} \cdot \mathrm{kg}^{-1}\right)\end{array}$ & $\begin{array}{c}\text { CP } 96,345 \\
\left(50 \mathrm{mg} \cdot \mathrm{kg}^{-1}\right)\end{array}$ & & \\
\hline Challenge & Saline & OVA & OVA & & \\
\hline
\end{tabular}

DMSO: dimethy sulphoxide. 
along the ventral midline and flattened between two glass slides held together by clips for $24 \mathrm{~h}$ in $100 \%$ ethanol at room temperature, cleared in toluene for 15 min, and mounted on a glass slide. Five images of the intercartilaginous portion from each tracheal preparation were viewed with image analysing software (MacScope; Mitani Co., Fukui, Japan) using an Apple Macintosh computer (Apple Computer Inc., Cupertino, CA, USA) connected to the microscope. The Monastral blue dye trapped between the endothelia was quantified as the area density [19], that is, the percentage area of mucosa occupied by vessels stained with Monastral blue in a site just proximal to the carina.

\section{Measurement of bradykinin and substance $P$ concen- trations in bronchoalveolar lavage fluid}

Because bradykinin and SP are decomposed by angiotensin converting enzyme (ACE) or neutral endopeptitase (NEP) in only a few minutes, the BALF was boiled immediately in order to inactivate these enzymes. The BALF was then stored at $-80^{\circ} \mathrm{C}$ until assay. The bradykinin and SP concentrations were quantified by radioimmunoassay (RIA). The BALF samples $(1 \mathrm{~mL})$ for bradykinin were mixed with isopropylalcohol $(2.5 \mathrm{~mL})$ and centrifuged at $1200 \times g, 4^{\circ} \mathrm{C}$ for $10 \mathrm{~min}$. The supernatant was mixed with petroleum ether $(2 \mathrm{~mL})$ and the upper layer was aspirated, and this step being performed twice. The lower layer was evaporated by nitrogen gas at $55^{\circ} \mathrm{C}$, mixed with tris-hydroxymethy-amino methane (Tris)-HCl buffer $(500 \mu \mathrm{L}, \mathrm{pH} 7.0)$ and centrifuged at $1200 \times g, 4^{\circ} \mathrm{C}$ for 5 min. The sample $(400 \mu \mathrm{L})$ or bradykinin standard (Peptide Institute, Inc., Osaka, Japan) was mixed with anti-bradykinin (100 $\mu \mathrm{L}$; SRL Inc., Tokyo, Japan) and stored overnight at $4{ }^{\circ} \mathrm{C}$. They were incubated with $100 \mu \mathrm{L}\left[{ }^{125} \mathrm{I}-\right.$ tyr $^{8}$ ]-bradykinin (Du Pont NEN Research Products, Boston, MA, USA) at $4{ }^{\circ} \mathrm{C}$ for $4 \mathrm{~h}$. The mixtures were mixed with $1 \% \gamma$-globulin $(100 \mu \mathrm{L})$ and $25 \%$ polyethylene glycol $(700 \mu \mathrm{L})$, and centrifuged at $1200 \times g, 4^{\circ} \mathrm{C}$ for 10 min to separate the antibody-bound form from the free peptide. The supernatant was discarded, and the radioactivity of the sediment was measured by a gamma counter (1261 Multi Gamma; Wallac Oy, Turku, Finland).

The BALF samples for SP were diluted with $4 \%$ acetic acid $\mathrm{pH} 4.0$ to a final volume of $50 \mathrm{~mL}$, homogenized using Polytron PT-10 (Kinematica AG, Littau, Switzerland), and centrifuged at $40,000 \times g$ for $30 \mathrm{~min}$. The supernatant was loaded onto reversed-phase C18 cartridges (Sep-Pak C18; Millipore Co., Milford, MA. USA). After washing with $20 \mathrm{~mL}$ of $4 \%$ acetic acid $\mathrm{pH} 4.0$ and $20 \mathrm{~mL}$ distilled water, SP was eluted with $2 \mathrm{~mL}$ of $80 \%$ acetonitrile in $0.1 \%$ trifluoroacetic acid. Eluates were concentrated by spin-vacuum evaporation, lyophylized, and the eluates dissolved using $0.15 \mathrm{~mL}$ of assay buffer $(50$ $\mathrm{mm}$ phosphate buffer, $\mathrm{pH} 7.2$, containing $3.7 \mathrm{mg} \cdot \mathrm{mL}^{-1}$ ethylene diamine tetra-acetic acid (EDTA) and $0.5 \%$ bovine serum albumin (BSA)) before being subjected to an RIA for SP. RIA for SP was performed using ${ }^{125} \mathrm{I}-\mathrm{SP}$ (Amersham International plc., Amersham, UK) and antiSP rabbit serum (Amersham International plc). A $0.1 \mathrm{~mL}$ sample was mixed with $0.5 \mathrm{~mL}$ assay buffer, $0.1 \mathrm{~mL}$ antiserum and $0.1 \mathrm{~mL}^{125} \mathrm{I}-\mathrm{SP}$, and stored at $4{ }^{\circ} \mathrm{C}$ for $24 \mathrm{~h}$. A total of $0.2 \mathrm{~mL}$ dextran/charcoal suspension $(0.2 \%$ dextran and $2 \%$ activated charcoal in assay buffer) was added to the reaction mixture and centrifuged at $2,000 \times g, 4{ }^{\circ} \mathrm{C}$, for $10 \mathrm{~min}$. The radioactivity of the supernatant was measured by a gamma counter (Model 5420A; Packard Instrument Co., Meriden, CT, USA). In this system, the sensitivity of detection of SP in saline was $1-60 \mathrm{fmol} \cdot \mathrm{mL}^{-1}$.

Quantification of eosinophil accumulation into the airways

The upper part of the trachea was immersed in $10 \%$ formalin for 3 days, before being embedded in paraffin and sectioned at a thickness of $4 \mu \mathrm{m}$. The sections were immersed in Hansel's stain solution for 30-45 s, followed by the addition of a drop of distilled water for a further 30 s. The slides were then flooded with distilled water followed by $95 \%$ methyl alcohol. The slides were then drained [20]. Eosinophils were counted in both the epithelial layer and submucosal area using a microscope.

\section{Drugs}

HOE 140 and CP 96,345 were kindly donated by Hoechst AG (Frankfurt, Germany) and Yamanouchi Pharmaceutical Co. Ltd. (Tukuba, Japan), respectively. Bradykinin, Monastral blue dye, OVA, pyrilamine and urethane were from Sigma Chemical Co. (St. Louis, MO, USA). SP was from Funakoshi Co. (Tokyo, Japan). Aluminum hydroxide, dimethyl sulphoxide (DMSO) and paraformaldehyde were from Wako Pure Chemical Industries (Osaka, Japan). Hansel's stain solution was from Torii Chemical Co. (Tokyo, Japan) Saline was from Ohtsuka Chemical Co. (Tokyo, Japan).

\section{Statistical analysis}

Data are expressed as mean \pm SEM. Multiple comparisons of mean data of dye extravasation and quantification of eosinophils among the groups were performed by one way analysis of variance (ANOVA), followed by Scheffe's test as a post hoc test. Comparisons of mean data of bradykinin and SP concentration in BALF among the groups were performed by the Mann-Whitney U-test. A p-value $<0.05$ was considered significant.

\section{Results}

Bradykinin $B_{2}$ - and neurokinin 1-receptor antagonists effect on bradykinin-and SP-induced airway microvascular permeability

Bradykinin administration caused significant airway microvascular permeability. This response was completely inhibited by HOE 140 pretreatment (fig. 1a). SP also showed significant airway microvascular permeability, and this response was almost completely abolished by CP 96,345 (fig. 1b). 

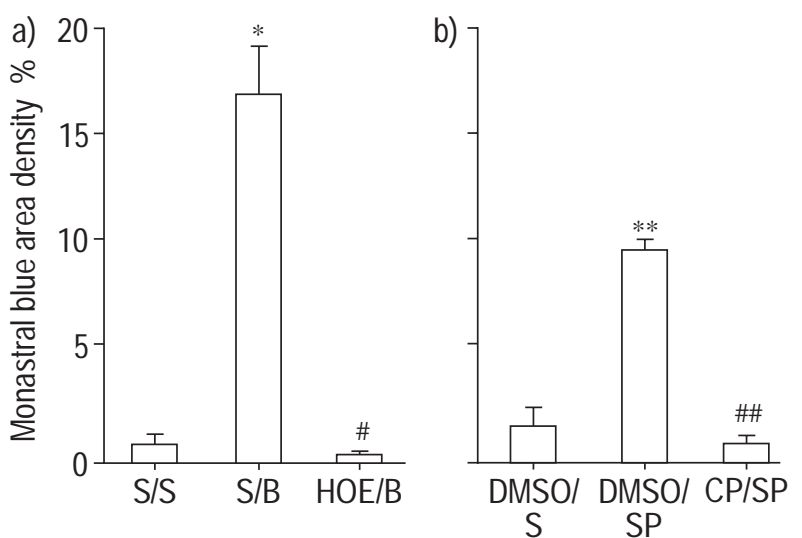

Fig. 1. - a) Effect of the bradykinin $\mathrm{B}_{2}$-receptor antagonist (HOE 140; $10 \mathrm{mg} \cdot \mathrm{kg}^{-1}$, s.c.) on bradykinin-induced airway microvascular permeability. S/S: Saline treated, saline injected group; S/B: saline treated, bradykinin injected group; HOE/B: HOE 140 treated, bradykinin injected group. ${ }^{*}: \mathrm{p}<0.01$, compared with the $\mathrm{S} / \mathrm{S}$ group; ${ }^{\#}: \mathrm{p}<0.01$, compared with the S/B group. b) Effect of neurokinin 1 receptor antagonist (CP 96,$345 ; 50 \mathrm{mg} \cdot \mathrm{kg}^{-1}$, i.p.) on substance $\mathrm{P}(\mathrm{SP})$-induced airway microvascular permeability. DMSO/S: dimethyl sulphoxide (DMSO) treated, saline injected group; DMSO/SP: DMSO treated, SP injected group; CP/ SP: CP 96,345 treated, SP injected group. ${ }^{* *}: \mathrm{p}<0.01$, compared with the $\mathrm{DMSO} / \mathrm{S}$ group; ${ }^{\# \#}: \mathrm{p}<0.01$, compared with the DMSO/SP group. All values are mean \pm SEM.

Bradykinin concentration in bronchoalveolar lavage fluid during the late allergic reaction

All animals showed a rapid breathing pattern and cyanosis during and immediately after OVA inhalation. About 45 min later, the animals' breathing pattern returned to the level of the pre-inhalation challenge. At 4.5-6 h after the inhalation, the Ptp values rose to twice that of the baseline values in OVA challenged but not in saline exposed animals.

OVA challenge caused a significant increase in the bradykinin concentration in the BALF $\left(105 \pm 83 \mathrm{pg} \cdot \mathrm{mL}^{-1}\right.$, $\mathrm{p}<0.05)$ compared with those of the saline exposed animals $\left(1.8 \pm 1.1 \mathrm{pg} \cdot \mathrm{mL}^{-1}\right)$ during the LAR (fig. 2$)$.

\section{Effect of bradykinin $B_{2}$-receptor antagonist}

OVA challenge caused remarkable Monastral blue dye extravasation in the saline treated animals compared with

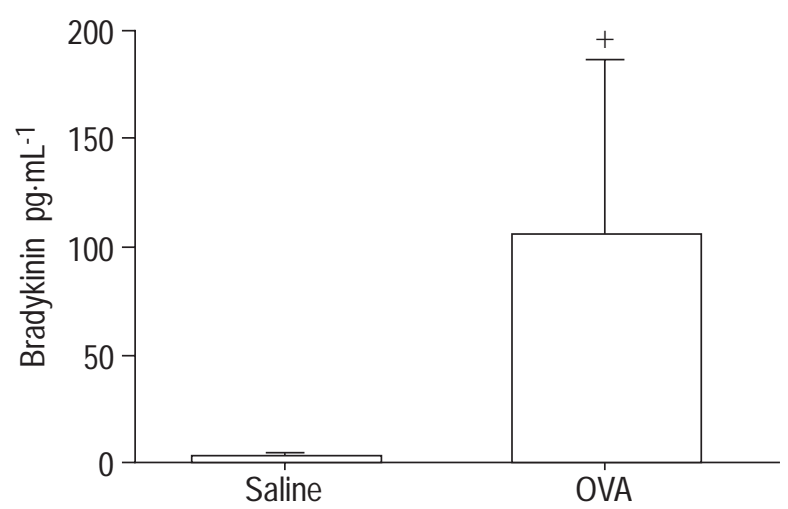

Fig. 2. - Bradykinin concentrations in the bronchoalveolar lavage fluid During the later allergic responses of the animals (LAR) after ovalbumin (OVA) inhalation or saline inhalation at a time matched to the LAR. All values are mean \pm SEM. ${ }^{+}: \mathrm{p}<0.05$, compared with the saline exposed group.
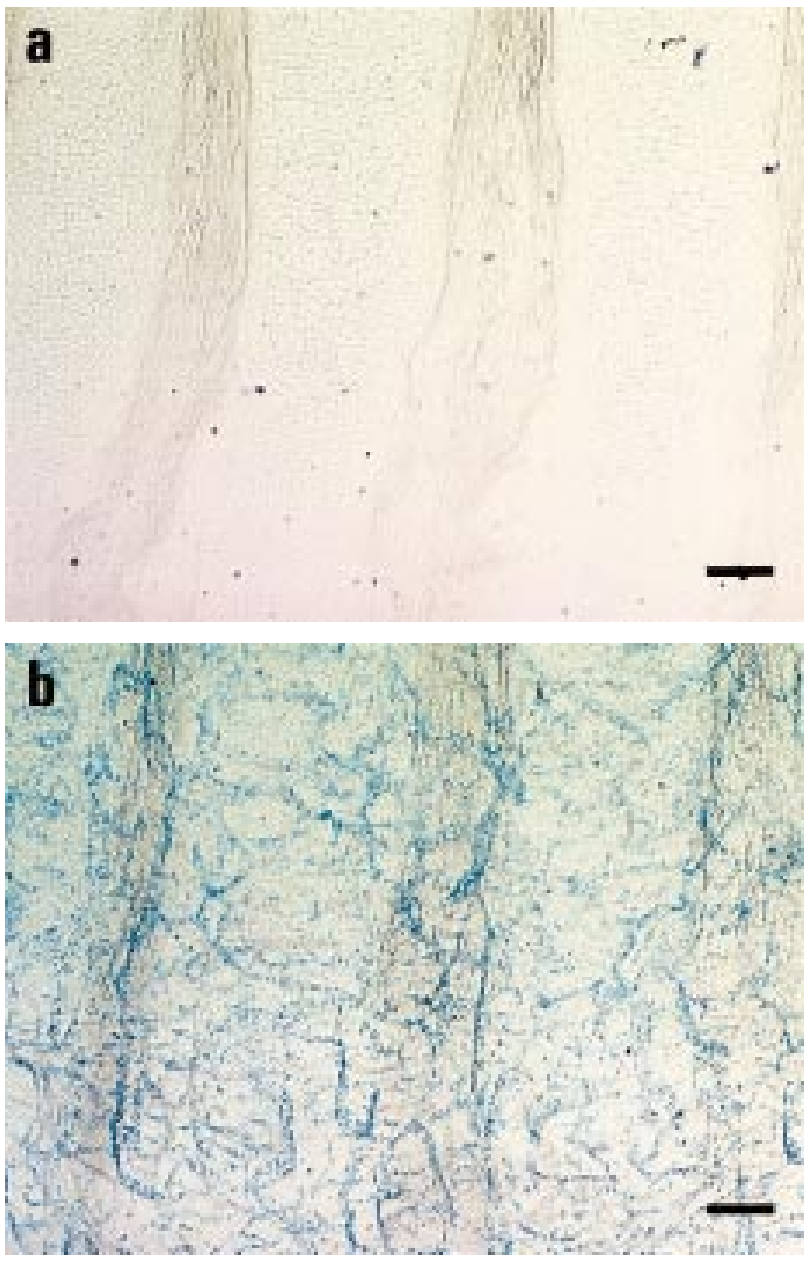

Fig. 3. - Representative view of Monastral blue labelled airway microvessels during the late allergic response in a) saline treated, saline exposed and b) saline treated, ovalbumin challenged animals. (Internal scale bar=300 $\mu \mathrm{m}$.)

those of the saline treated-saline exposed group during the LAR (fig. 3). Monastral blue dye trapping was observed at the vessels of $10-20 \mu \mathrm{m}$ in width, which is compatible with the size of postcapillary venules [18]. The effects of HOE 140 are summarized in figure 4 . HOE 140 pretreatment significantly inhibited the OVA-induced airway microvascular permeability in a dose-dependent manner. Figure 5 shows a representative view of eosinophil accumulation in the saline exposed and OVA challenged groups during the LAR. OVA inhalation caused a significant eosinophil accumulation both in the epithelium $\left(1.5 \pm 0.9-12.9 \pm 2.0\right.$ cells $\left.\cdot 100 \mathrm{~mm}^{-2 p i t h e l i u m}{ }^{-1}, \mathrm{p}<0.01\right)$ and submucosa $\left(2.2 \pm 1.2-23.6 \pm 2.9\right.$ cells $\cdot 10,000 \mu \mathrm{m}^{2}$ sub$\left.\operatorname{mucosa}^{-1}, \mathrm{p}<0.01\right)$ during the LAR compared with the saline exposed group. HOE 140 pretreatment did not affect the eosinophil accumulation (fig. 6).

The relationship between bradykinin and SP during the LAR was then investigated. In the saline treated animals, OVA challenge caused a significant increase in the SP concentration in the BALF compared to the saline treated, saline exposed animals during the LAR (fig. 7). HOE 140 pretreatment reduced the SP concentration in the BALF in a dose-dependent manner. 


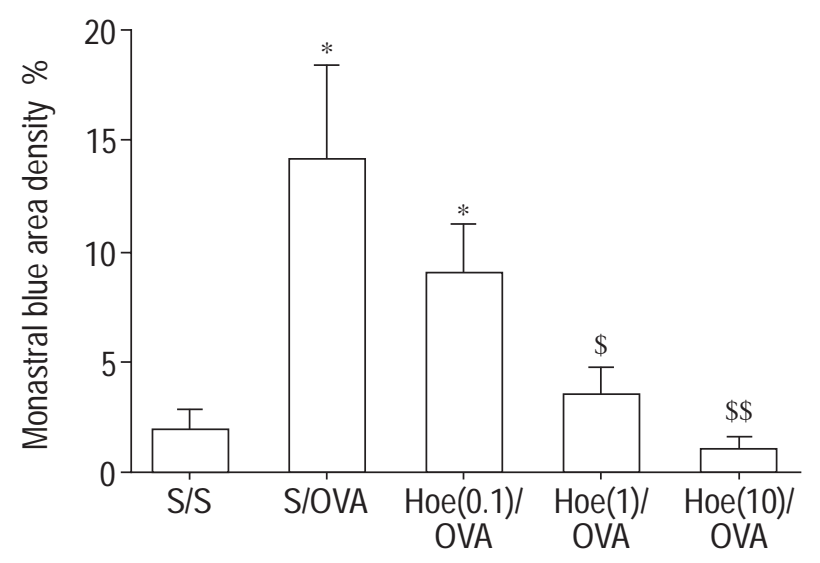

Fig. 4. - Effect of the bradykinin $\mathrm{B}_{2}$-receptor antagonist (HOE 140) on airway microvascular permeability during the late allergic response. $\mathrm{S} / \mathrm{S}$ : Saline treated, saline challenged group; S/OVA: saline treated, ovalbumin (OVA) challenged group; HOE(0.1)/OVA, HOE(1)/OVA, HOE (10)/OVA: HOE $140\left(0.1,1\right.$ or $\left.10 \mathrm{mg} \cdot \mathrm{kg}^{-1}\right)$ treated, OVA challenged group. All values are mean \pm SEM. *: $\mathrm{p}<0.01$, compared with the $\mathrm{S} / \mathrm{S}$ group; ${ }^{\$}: \mathrm{p}<0.05, \$ \$$ : $<<0.01$, compared with the $\mathrm{S} / \mathrm{OVA}$ group.

\section{Effect of neurokinin 1-receptor antagonist}

OVA challenge caused significant Monastral blue dye extravasation in the DMSO-treated animals compared with the DMSO-treated, saline exposed group during the LAR (fig. 8). CP 96,345 pretreatment almost completely inhibited the dye extravasation. Figure 9 shows the effects of CP 96,345 on eosinophil accumulation during the LAR. CP 96,345 pretreatment did not show an inhibitory effect on eosinophil accumulation.

\section{Discussion}

These data show that allergen inhalation causes significant airway microvascular permeability and eosinophil accumulation into the airway during the LAR. During this period, both the bradykinin and SP concentrations in the BALF were increased. Furthermore, each bradykinin $\mathrm{B}_{2}$ and $\mathrm{NK}_{1}$ receptor antagonist significantly inhibited the airway microvascular permeability during the LAR. These results suggest that the bradykinin-tachykinins pathway, that is sensory nerve activation, plays an important role in microvascular permeability during the LAR in sensitized guinea-pigs.

Bradykinin is formed from kininogens by the action of plasma and tissue kallikrein $[2,21]$. In allergen inhalation challenge, it has been reported that both plasma and tissue kallikrein release and/or activation occurs [7]. ERJEFÄLT et al. [14] have also reported that the bradykinin concentration increases during the LAR, which is in agreement with the present results. Bradykinin has a variety of airway actions including airway smooth muscle contraction, hypersecretion and microvascular permeability via bradykinin $B_{2}$ receptors $[3,21]$, and is thought to be an important mediator in asthmatic airway inflammation [21]. Bradykinin-induced airway microvascular permeability has been reported to occur via two pathways. One pathway is its direct action in the endothelium and the
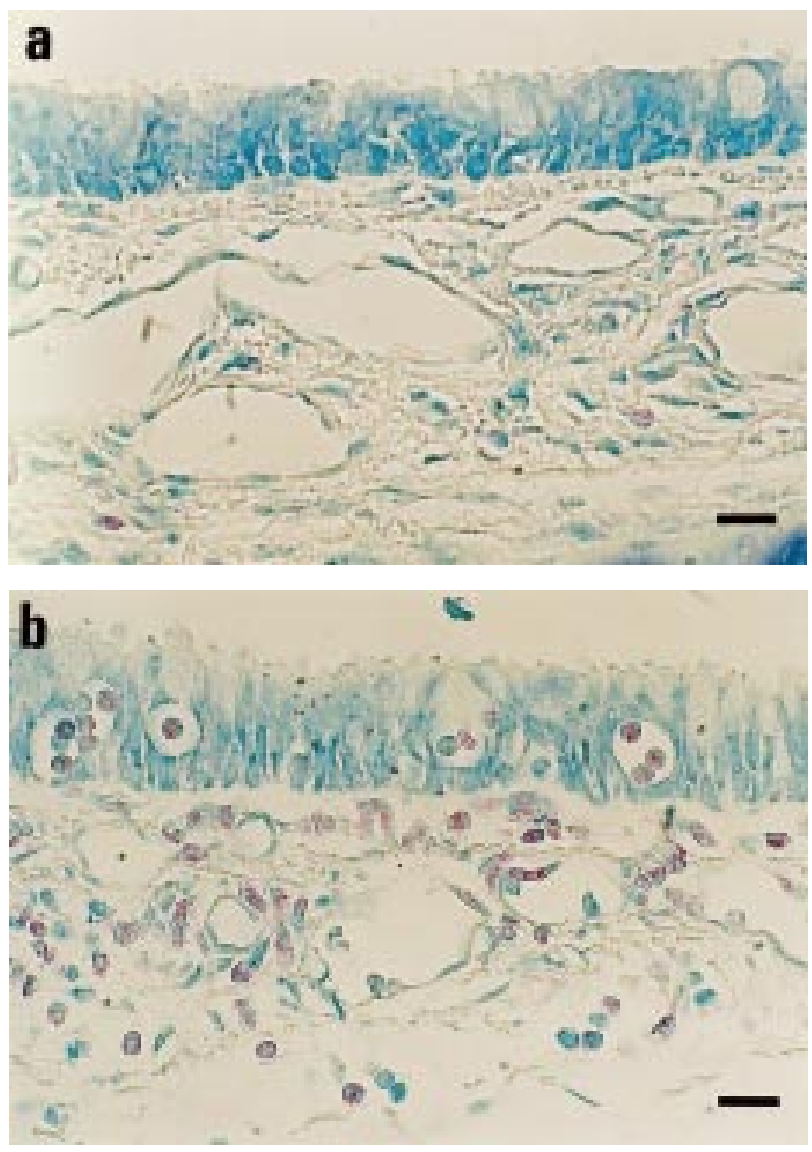

Fig. 5. - Eosinophil accumulation within the airway wall during the late allergic response. a) In the saline treated, saline exposed animals, few eosinophils were seen. b) Many more eosinophils accumulated both in the epithelium and submucosa in the saline treated, ovalbumin challenged animals. (Internal scale bar $=20 \mu \mathrm{m}$.)

other is an indirect mechanism that involves tachykinin release $[22,23]$. In the present study, the bradykinin $\mathrm{B}_{2^{-}}$ receptor antagonist-induced reduction in the SP concentration in the BALF was in parallel with the inhibition of microvascular permeability. Therefore, during the LAR, bradykinin seems to cause airway microvascular permeability via tachykinin release.

In the airways, tachykinins are thought to be released from sensory C-fibres via axon reflex mechanisms [9, 10]. Among the endogenous molecules, bradykinin is one of the most potent stimulators of C-fibres [3, 21]. Tachykinins cause airway microvascular leakage via activation of $\mathrm{NK}_{1}$ receptors in the endothelial cells of post capillary venules $[18,24]$. In the present study, the NK1 receptor antagonist CP 96,345 completely inhibited the airway microvascular permeability during the LAR, strongly suggesting that $\mathrm{NK}_{1}$ receptor activation in the endothelial cells and the resulting contraction of the cells are the final steps that lead to the airway microvascular permeability during the LAR in guinea-pigs.

In asthmatic animal models, allergen challenge causes immediate and late airway responses $[12,13]$. The immediate phase response is mainly via airway smooth muscle contraction mediated by mast cell-derived mediators including histamine and leukotrienes. On the other hand, the late phase response is due to airway inflammation 
a)

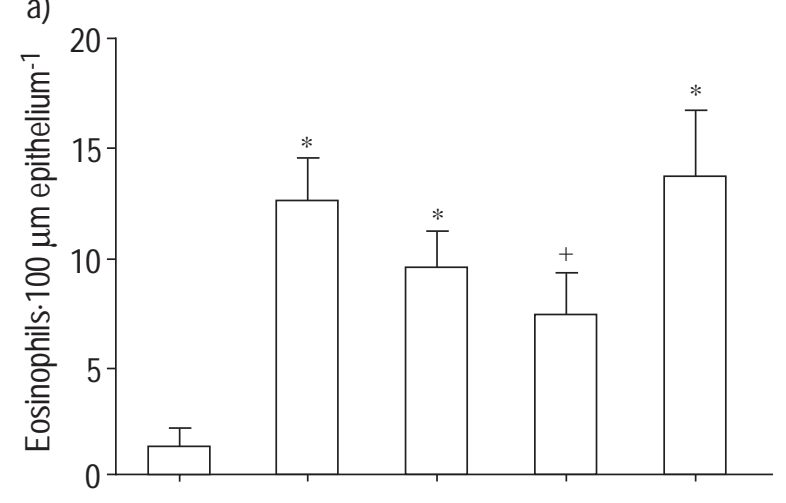

b)

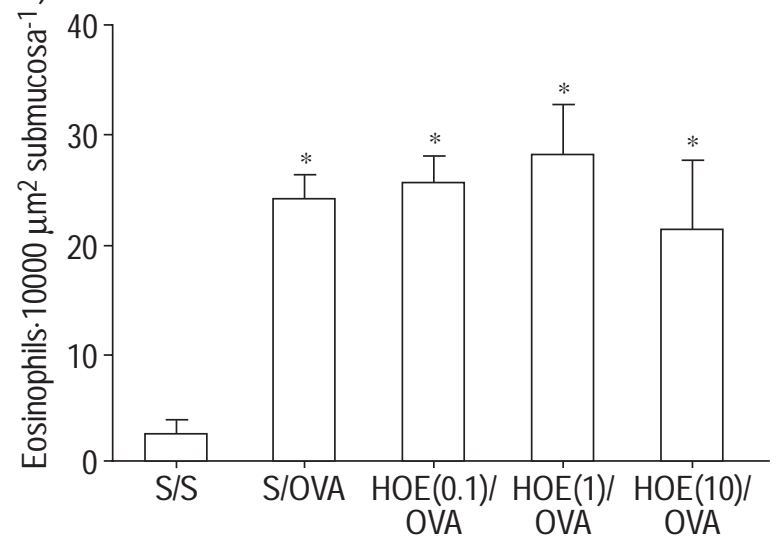

Fig. 6. - Effect of the bradykinin $B_{2}$-receptor antagonist (HOE 140) on eosinophil infiltration during the late allergic response in the a) epithelium and b) submucosa. S/S: Saline treated, saline challenged group; S/OVA: saline treated, ovalbumin (OVA) challenged group; $\operatorname{HOE}(0.1) /$ OVA, HOE(1)/OVA, HOE (10)/OVA: HOE $140\left(0.1,1\right.$ or $\left.10 \mathrm{mg} \cdot \mathrm{kg}^{-1}\right)$ treated, OVA challenged group. All values are mean \pm SEM. ${ }^{+}: \mathrm{p}<0.05, *$ : $\mathrm{p}<0.01$, compared with the $\mathrm{S} / \mathrm{S}$ group.

such as airway wall oedema and mucus secretion [12, 13], which is very similar to asthmatic chronic airway inflammation. To elucidate the inflammatory mechanisms, animal models including guinea-pigs [14], rats [25, 26] and dogs [27] have been developed using vascular permeability as the marker of inflammation. The present study is the first report showing that the bradykinin-tachykinins pathway, that is sensory nerve activation, is a major contributor to airway microvascular permeability, which has a key role in airway wall oedema during the LAR.

In the present study, both bradykinin $\mathrm{B}_{2^{-}}$and $\mathrm{NK}_{1}$ receptor antagonists almost completely inhibited the airway microvascular permeability during the LAR. In contrast, eosinophil accumulation into the airway during this period was not affected by the antagonists. Microvascular permeability has been reported to be mainly due to endothelial contraction in the smallest postcapillary venules $[18,28]$. Both bradykinin and SP are potent inducers of permeability. Previously, it has been reported that bradykinin-induced tracheal microvascular permeability is largely reduced by $\mathrm{NK}_{1}$-receptor antagonists [22], which is compatible with the present results. On the other hand, eosinophil recruitment into the airways occurs in the largest postcapillary venules $[18,29]$ and is mainly regulated by chemical factors including cytokines, adhesion molecules and chemokines. Thus, the site and

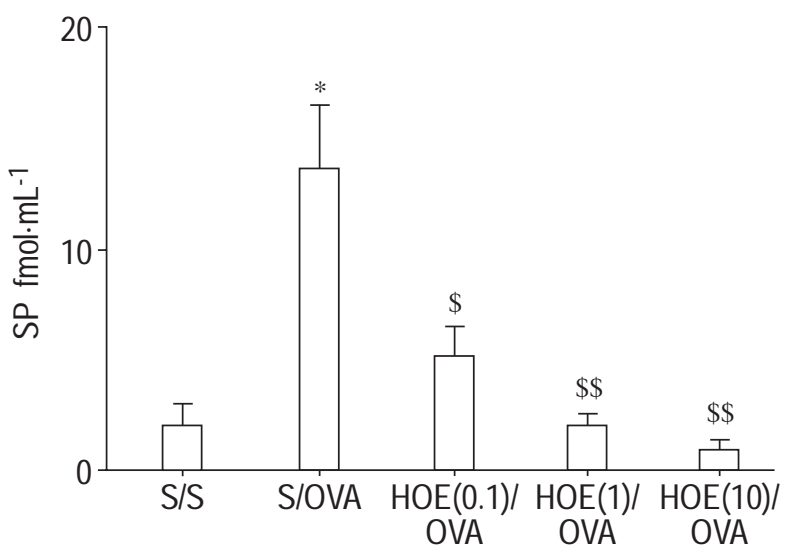

Fig. 7. - Effect of the bradykinin $\mathrm{B}_{2}$-receptor antagonist (HOE 140) on substance $\mathrm{P}$ (SP) concentration in the BALF of guinea-pigs during the late allergic reaction. $\mathrm{S} / \mathrm{S}$ : Saline treated, saline challenged group; $\mathrm{S}$ / OVA: saline treated, ovalbumin (OVA) challenged group; $\mathrm{HOE}(0.1) /$ OVA, HOE(1)/OVA, HOE (10)/OVA: HOE $140\left(0.1,1\right.$ or $\left.10 \mathrm{mg} \cdot \mathrm{kg}^{-1}\right)$ treated, OVA challenged group. All values are mean \pm SEM. $*: \mathrm{p}<0.01$, compared with the $\mathrm{S} / \mathrm{S}$ group; ${ }^{\$}: \mathrm{p}<0.05,{ }^{\$}: \mathrm{p}<0.01$, compared with $\mathrm{S} /$ OVA group.

mechanisms of airway microvascular permeability and eosinophil accumulation seem to be different. The bradykinin-tachykinins pathway may not work in the largest postcapillary venules nor be involved in the cytokine, adhesion molecule and chemokine systems.

Monastral blue dye was used to assess the airway microvascular permeability. The particles of Monastral blue are too large to cross the endothelium of tracheal blood vessels with a normal permeability. However, when the blood vessels become more permeable, possibly due to the endothelial contraction, the dye passes through gaps in the endothelium and is trapped by the basal lamina where it remains and thus labels the site of extravasation $[18,24$, 28].

In conclusion, these results have demonstrated that both bradykinin $\mathrm{B}_{2^{-}}$and $\mathrm{NK}_{1}$-receptor antagonists almost completely inhibited the airway microvascular permeability but not the eosinophil accumulation during the late allergic reaction. Airway microvascular permeability is an

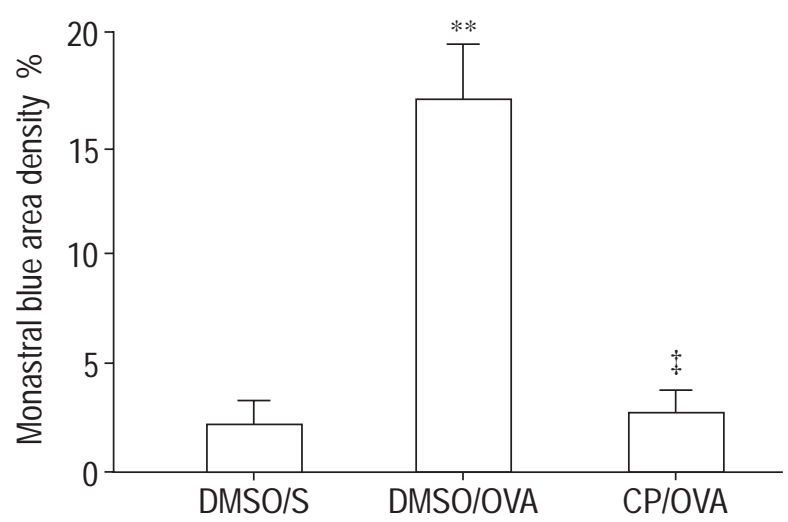

Fig. 8. - Effect of the neurokinin 1 receptor antagonist (CP 96,345) on airway microvascular permeability during the late allergic response. $\mathrm{DMSO} / \mathrm{S}$ : dimethyl sulphoxide (DMSO) treated, saline challenged group; DMSO/OVA: DMSO treated, ovalbumin (OVA) challenged group; $\mathrm{CP} /$ OVA: CP 96,345 treated, OVA challenged group. All values are mean \pm SEM. **: $\mathrm{p}<0.01$, compared with the DMSO/S group; ${ }^{*}: \mathrm{p}<0.01$, compared with the DMSO/OVA group. 
a)

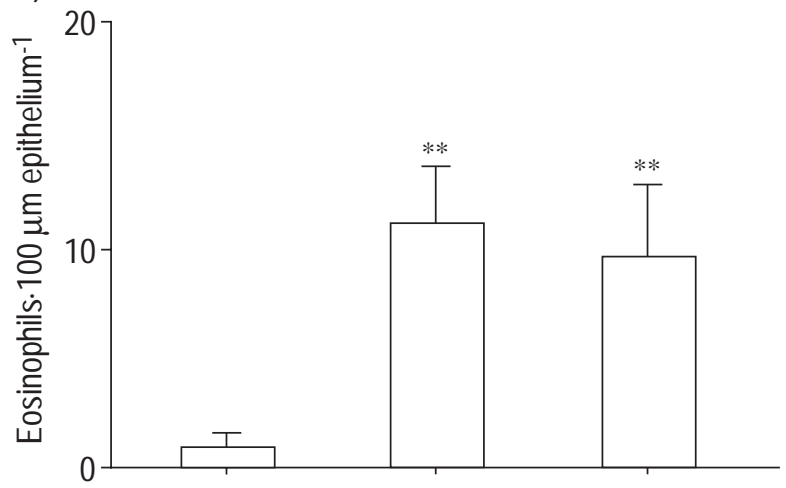

b)

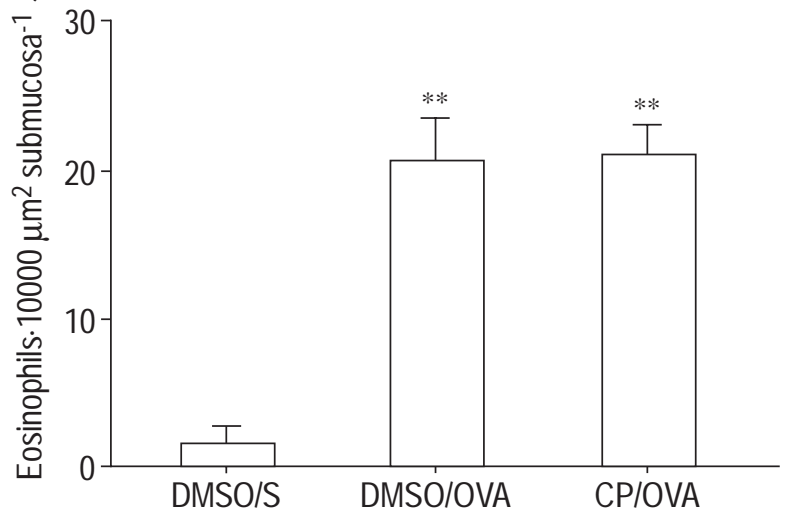

Fig. 9. - Effect of the neurokinin 1 receptor antagonist (CP 96,345) on eosinophil infiltration during the late allergic response in the a) epithelium and b) submucosa. DMSO/S: dimethyl sulphoxide (DMSO) treated, saline challenged group; DMSO/OVA: DMSO treated, ovalbumin (OVA) challenged group; CP/OVA: CP 96,345 treated, OVA challenged group. All values are mean $\pm \mathrm{SEM}$. ${ }^{* *}$ : $\mathrm{p}<0.01$, compared with the $\mathrm{DMSO} / \mathrm{S}$ group.

important factor of airway inflammation in asthma [3033]. Further, neutral endopeptidase, which is responsible for the degradation of both bradykinin and tachykinins, is mainly localized in airway epithelial cells [34]. Because airway epithelial shedding is frequently observed in asthmatic airways, exaggerated sensory nervous pathway via inactivation of the peptide may have a key role [9]. Therefore, inhibition of the bradykinin-tachykinins pathway may become useful for asthma treatment in the future.

Acknowledgement. The authors thank B. Bell for reading the manuscript.

\section{References}

1. Proud D, Kaplan AP. Kinin formation: mechanisms and role in inflammatory disorders. Ann Rev Immunol 1988; 6: 49-83.

2. Regoli D, Barabe J. Pharmacology of bradykinin and related kinins. Pharmacol Rev 1980; 32: 1-46.

3. Ichinose M, Barnes PJ. Bradykinin-induced airway microvascular leakage and bronchoconstriction are mediated via a bradykinin B2 receptor. Am Rev Respir Dis 1990; 142: 1104-1107.

4. Ichinose M, Belvisi MG, Barnes PJ. Bradykinin-induced bronchoconstriction in guinea pig in vivo: role of neu- ral mechanisms. J Pharmacol Exp Ther 1990; 253: 594 599.

5. Fuller RW, Dixon CMS, Cuss FMC, Barnes PJ. Bradykinin-induced bronchoconstriction in humans: mode of action. Am Rev Respir Dis 1987; 135: 176-180.

6. Christiansen SC, Proud D, Cochrane CG. Detection of tissue kallikrein in the bronchoalveolar lavage fluid of asthmatic subjects. J Clin Invest 1987; 79: 188-197.

7. Christiansen SC, Proud D, Sarnoff RB, Juergens U, Cochrane CG, Zuraw BL. Elevation of tissue kallikrein and kinin in the airways of asthmatic subjects after endobronchial allergen challenge. Am Rev Respir Dis 1992; 145: 900-905.

8. Lundberg JM, Saria A. Capsaicin-induced desensitization of airway mucosa to cigarette smoke, mechanical and chemical irritants. Nature 1983; 302: 251-253.

9. Barnes PJ. Asthma as an axon reflex. Lancet 1986; 1: 242-245.

10. Ichinose $M$, Nakajima $\mathrm{N}$, Takahashi $\mathrm{T}$, Yamauchi $\mathrm{H}$, Inoue $\mathrm{H}$, Takishima $\mathrm{T}$. Protection against bradykinin-induced bronchoconstriction in asthmatic patients by neurokinin receptor antagonist. Lancet 1992; 20: 1248-1251.

11. Bertrand C, Nadel JA, Yamawaki I, Geppetti P. Role of kinins in the vascular extravasation evoked by antigen and mediated by tachykinins in guinea pig trachea. $J$ Immunol 1993; 151: 4902-4907.

12. Sheth KK, Lemanske Jr RF. The early and late asthmatic response to allergen. In: Busse WW, Holgate ST, eds. Asthma and Rinitis. Boston, Blackwell Scientific Publications, 1995; pp. 946-960.

13. Lemanske Jr RF, Kaliner MA. Late phase allergic reactions. In: Middleton E Jr, Reed CE, Ellis EF, Adkinson NF Jr, Yunginger JW, Busse WW, eds. Allergy Principles and Practice, 4th Edn. St. Louis, The C.V. Mosby Company, 1993; pp. 320-361.

14. Erjefält I, Greiff L, Alkner ULF, Persson CGA. Allergen-induced biphasic plasma exudation responses in guinea pig large airways. Am Rev Respir Dis 1993; 148: 695-701.

15. Abraham WM, Burch RM, Farmer SG, Sielczak MW, Ahmed A, Cortes A. A bradykinin antagonist modifies allergen-induced mediator release and late bronchial responses in sheep. Am Rev Respir Dis 1991; 143: 787-796.

16. Andersson P. Antigen-induced bronchial anaphylaxis in actively sensitized guinea-pigs. Pattern of response in relation to immunization regimen. Allergy 1980; 35: 6571.

17. Noonan TC, Gundel RH, Desai SN, et al. The effects of an anti-CD18 antibody (R15.7) in antigen-induced airway hyperresponsiveness $(\mathrm{AH})$ and cell influx in guinea pigs. Agents Actions 1991; 34: 211-213.

18. McDonald DM. Endothelial gaps and permeability of venules in rat tracheas exposed to inflammatory stimuli. Am J Physiol 1994; 266: L61-83.

19. Umeno E, McDonald DM, Nadel JA. Hypertonic saline increases vascular permeability in the rat trachea by producing neurogenic inflammation. J Clin Invest 1990; 85: 1905-1908.

20. Hansel FK. The cytology of the secretions in allergy. In: Clinical Allergy. St. Louis, The C.V. Mosby Company, 1953; pp. 408-419.

21. Barnes PJ, Chung KF, Page CP. Inflammatory mediators and asthma. Pharmacol Rev 1988; 40: 49-84.

22. Nakajima N, Ichinose M, Takahashi T, et al. Bradykinininduced airway inflammation. Contribution of sensory neuropeptides differs according to airway site. Am J Respir Crit Care Med 1994; 149: 694-698. 
23. Lundberg JM, Salia A, Brodin E, Russell S, Forkers K. A substance $\mathrm{P}$ antagonist inhibits vagally induced increase in vascular permeability and bronchial smooth muscle contraction in guinea-pig. Proc Natl Acad Sci USA. 1983; 80: $1120-1124$.

24. Baluk P, Hirata A, Thurston G, et al. Endothelial gaps: time course of formation and closure in inflamed venules of rats. Am J Physiol 1997; 272: L155-170.

25. Bolton PB, Lefevre P, McDonald DM. Salmeterol reduces early and late-phase plasma leakage and leukocyte adhesion in rat airways. Am Rev Respir Dis 1997; 155: 14281435.

26. Baluk P, Bolton PB, Hirata A, Thurston G, McDonald DM. Endothelial gaps and adherent leukocytes in allergen-induced early- and late-phase plasma leakage in rat airways. Am J Pathol 1998; 152: 1463-1476.

27. Ohrui T, Sekizawa K, Aikawa T, Yamauchi K, Sasaki $\mathrm{H}$, Takishima T. Vascular permeability and airway narrowing during late asthmatic response in dogs treated with metopirone. J Allergy Clin Immunol 1992; 89: 933943.

28. McDonald DM. Neurogenic inflammation in the rat tra- chea. I. Changes in venules, leucocytes and epithelial cells. J Neurocytol 1988; 17: 583-603.

29. Baluk P, Bertrand C, Geppetti P, McDonald DM, Nadel JA. NK1 receptors mediate leukocyte adhesion in neurogenic inflammation in the rat trachea. Am J Physiol 1995; 268: L263-269.

30. Persson CGA. Plasma exudation and asthma. Lung 1988; 166: 1-23.

31. McFadden ER Jr. Hypothesis: exercise-induced asthma as a vascular phenomenon. Lancet 1990; 335: 880-883.

32. Yager D, Shore S, Drazen M. Airway luminal liquid: sources and role as an amplifier of bronchoconstriction. Am Rev Respir Dis 1991; 143: S52-54.

33. Kimura K, Inoue H, Ichinose M, Miura M, et al. Bradykinin causes airway hyperresponsiveness and enhances maximal airway narrowing. Role of microvascular leakage and airway edema. Am Rev Respir Dis 1992; 146: 1301-1305.

34. Sekizawa K, Tamaoki J, Graf PD, Basbaum CB, Borson DB, Nadel JA. Enkephalinase inhibitor potentiates mammalian tachykinin-induced contraction in ferret trachea. $J$ Pharmacol Exp Ther 1987; 243: 1211-1217. 